Journal of Food Technology 9 (3): 91-94, 2011

ISSN: $1684-8462$

(C) Medwell Journals, 2011

\title{
Production of Fructoligsaccharides by Aureobasidium pullulans Using Immobilization Technique
}

\author{
M.A. Ganaie, L.K. Pathak and U.S. Gupta \\ Microbiology Lab, Department of Zoology, H.S. Gour Central University, Sagar, MP, India
}

\begin{abstract}
The high content of fructooligosaccharides production from sucrose using fructosyltransferase from Aureobasidium pullulans was investigated in the laboratory by using immobilizing technique. The FOS production was obtained using both extracellular and intracellular enzyme from Aureobasidium pullulans. Optimum conditions for enzyme production and enzyme reaction have been determined.
\end{abstract}

$\underline{\text { Key words: Fructooligosaccharides, immobilization, fructosyltransferase enzyme, production, laboratory, India }}$

\section{INTRODUCTION}

Carbohydrate occur in nature as poly and hetro-functional mono, oligo and polysaccharides and are essential carbon sources for many bacteria, yeast and fungi. Biotechnological conversion of carbohydrates gives rise to broad range of derivatives with interesting and often unique potentials for applications in different types of industries e.g., detergent, cosmetic, food, pharmaceutical and chemical industries. Oligosaccharides are important in sweetener industry because of their wide applications such as low calorie sweetener for diabetics and functional food for enhancing growth of intestinal microorganisms (Oku et al., 1984; Hidaka et al., 1986; Yun et al., 1994). These well-known oligosaccharides are cyclodextrins (Hara et al., 1994), isomalto-oligosaccharides (Kohmoto et al., 1991), soybean-oligosaccharides (Wada et al., 1992) and fructooligosaccharides (Hidaka et al., 1988; Jung et al., 1993; Yun and Song, 1993). Among these new commercially available products, the Fructooligosaccharides (FOS) obtained from sucrose have attracted special attention due to their properties and thus have a great economic potential for the sugar industrial branch. FOS are of low caloric value as they are not hydrolyzed by the gastro-intestinal enzymes, promoting selectively the growth of the bifid bacteria in the colon (Moore et al., 2003), helping to eliminate the harmful microbial species to human and animal health and preventing colon cancer (Gibson and Roberfroid, 1995). FOS has also many important physiological properties such as they are non cariogenic, safety for diabetes, reduce cholesterol, phospholipids and triglyceride levels in blood (Tokunaga et al. 1989). Fructooligosaccharides (FOS) are oligosaccharides of fructose containing a single glucose moiety. FOS is industrially produced through fructosyl transfer from sucrose using microorganisms especially fungi and these fungal enzymes are too present in many higher plants (asparagus, chicory, onion, Jerusalem artichoke, etc). FOS producing enzymes are assigned as hydrolases ( $\beta$ fructofuranosidases, EC 3.2.1.26) or fructosyltransferases (transfructosidases, $\mathrm{EC}$ 2.4.1.9). The maximal FOS production for a particular enzyme depends on the relative rate of transfructosylation and hydrolysis. FOS are mainly composed of 1-kestose $\left(\mathrm{GF}_{2}\right)$, nystose (GF3) and 1$\beta$-fructofuranosyl nystose $\left(\mathrm{GF}_{4}\right)$ in which fructosyl units (F) are bound at the $\beta(2 \rightarrow 1)$ bonds with terminal $\alpha$ linked D glucose (Sangeetha et al., 2005; Yun, 1996; Hidaka et al., 1988) (Fig. 1).

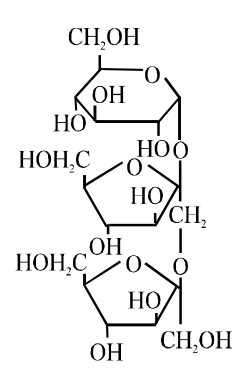

Kestose (GF2)

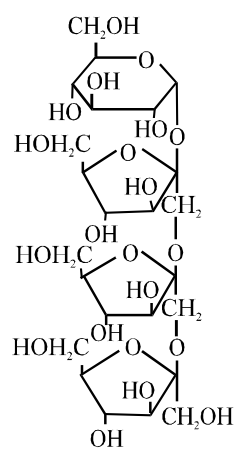

Nystose (GF3)

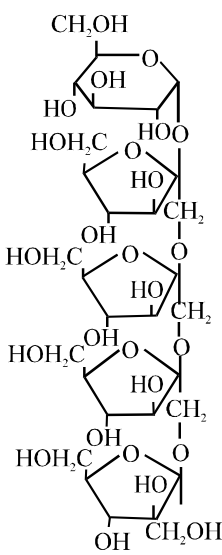

Fructofuranosyl nytose (GF4)
Fig. 1: Composition of FOS

Corresponding Author: Mohd Anis Ganaie, Microbiology Lab, Department of Zoology, H.S. Gour Central University, Sagar, MP, India 


\section{MATERIALS AND METHODS}

Chemicals: All chemicals used were of analytical grade. FOS standards were from Sigma USA and glucose, fructose were from Otto and sucrose of food grade.

Microorganisms and culture conditions: The microbial slant of Aureobasidium pullulans was taken from NCL Pune of ATCC No. 20524. The inoculums was developed by transferring of full lope of spores into $50 \mathrm{~mL}$ media containing $0.2 \%$ yeast extract and $1 \%$ sucrose $(\mathrm{pH} 5.5)$. The culture were kept in shaker incubator keeping its rpm 220 and temperature $28^{\circ} \mathrm{C}$ for $24 \mathrm{~h}$.

Production of fructosyltransferase enzyme: For enzyme production the media was prepared in $250 \mathrm{~mL}$ flask and added amount of culture media was $100 \mathrm{~mL}$. The composition of the culture medium was sucrose $20 \mathrm{~g}$, $\mathrm{NaNO}_{3} 1 \mathrm{~g}, \mathrm{~K}_{2} \mathrm{HPO}_{4}, 0.5 \mathrm{~g}$, yeast extract $0.5 \mathrm{~g}, \mathrm{MgSO}_{4} .7 \mathrm{H}_{2} \mathrm{O}$ $0.5 \mathrm{~g}$ and $\mathrm{NaCl} 0.25 \mathrm{~g}$ autoclaving $125^{\circ} \mathrm{C}$ for $20 \mathrm{~min}$. The $10 \mathrm{~mL}$ of $24 \mathrm{~h}$ old inoculums was transferred into $100 \mathrm{~mL}$ culture media with $1 \mathrm{~mL}$ spore suspension containing around $1.89 \times 10^{7}$ spores $\mathrm{mL}^{-1}$ and incubated at $30^{\circ} \mathrm{C}$ with shaking at $240 \mathrm{rpm}$ for $24-120 \mathrm{~h}$ with regular sampling at $24 \mathrm{~h}$ intervals to measure the enzyme activity. After incubation the culture media is centrifuged at $6000 \mathrm{rpm}$ for $20 \mathrm{~min}$ at $4^{\circ} \mathrm{C}$. After centrifugation the supernatant was used as a source of extracellular enzyme and the remaining pellet as intracellular enzyme.

Enzyme assay: For determining of enzyme activity $2.5 \mathrm{~mL}$ of enzyme is mixed with sucrose solution $60 \% \mathrm{w} / \mathrm{v}$ as substrate, $0.2 \mathrm{M}$ citrate buffer ( $\mathrm{pH} 5.5$ ) and incubated at $55^{\circ} \mathrm{C}$ for $1 \mathrm{~h}$ using shaker incubator from Lark. The reaction was terminated by keeping reaction mixture in water bath of $100^{\circ} \mathrm{C}$ for $15 \mathrm{~min}$. Glucose, fructose and trisaccharides like $\mathrm{GF}_{2}, \mathrm{GF}_{3}$ and $\mathrm{GF}_{4}$, etc. were then determined by HPLC. One unit of activity of transfructosylation is defined as amount of enzyme activity which catalyses the formation of $1 \mu \mathrm{mol}$ glucose per min and one unit of hydrolytic activity was defined as the amount of enzyme which catalyses the formation of $1 \mu \mathrm{mol}$ fructose per min under these conditions. Qualitative analysis was done by TLC and quantitave analysis was done by HPLC.

Production of FOS by immobilization technique: After completion of cultivation, the microorganisms were collected and immobilized in sodium alginate to produce fructooligosaccharides. The microorganisms at a certain concentration of $20 \% \mathrm{w} / \mathrm{v}$ were mixed with the sodium alginate and the mixture was extruded drop wise through needle (1D $1.0 \mathrm{~mm}$ ) into $0.1 \mathrm{M} \mathrm{CaCl}_{2}$ solution by peristaltic pump. Droplets were instantly transformed into spherical beads (2-3 $\mathrm{mm}$ in diameter) by exchange of $\mathrm{Na}^{+}$in droplets and $\mathrm{Ca}^{+}$in solution. The immobilized cells (beads) were kept in $2 \%$ of calcium chloride solution for enzymatic reaction and the microorganisms at a concentration of $20 \mathrm{~g}$ were mixed with the sodium alginate at a concentration of $1 \% \mathrm{w} / \mathrm{v}$.

Fructooligosaccharide production: FOS production was carried out using $55 \%$ concentrations of sucrose $\mathrm{w} / \mathrm{v}$ ). The extracellular enzymes of $2.5 \mathrm{~mL}$ were mixed with $7.5 \mathrm{~mL}$ sucrose $\mathrm{w} / \mathrm{v}$ and incubated at $55^{\circ} \mathrm{C}$ in shaker incubator at $220 \mathrm{rpm}$. The reaction was carried out as a function of time from 1-36 h. After incubaton the reaction was stopping by putting the reaction mixture in a water bath for $20 \mathrm{~min}$ at $100^{\circ} \mathrm{C}$. The products in the reaction mixture were analyzed both qualitatively by TLC in Fig. 2 and quantitavely by HPLC (Fig. 3).

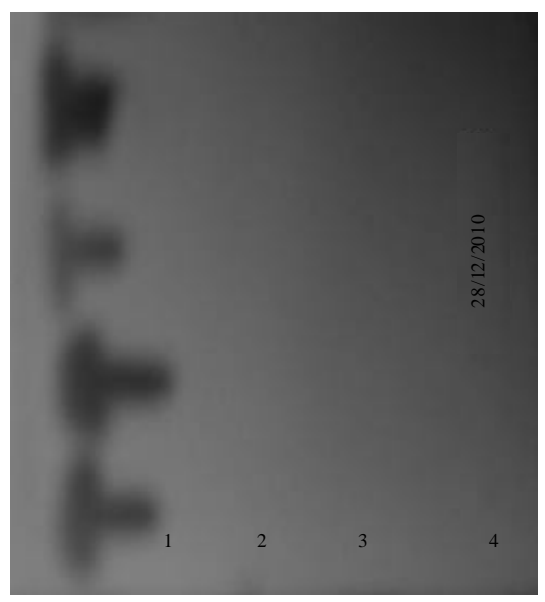

Fig. 2: TLC analysis shows 1: Sucrose; 2: Glucose, 3: Fructose; 4: FOS

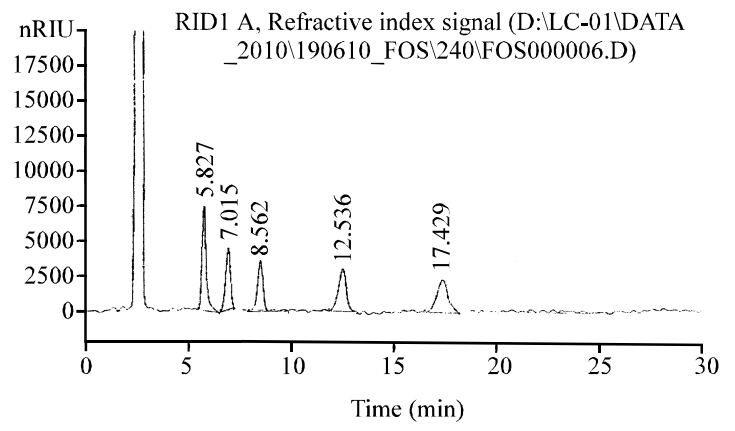

Fig. 3: Typical HPLC chromatogram of standard solution FOS (retention time of fructose-5.827, glucose7.015 , sucrose-8.562, kestose-12.536, nystose17.429) 
The thin layer chromatography coated on glass plates consists of solvent system 1-propanol: ethyl acetate: water $6: 2: 2$ ratio. The plates were developed using spray solution consists of $5 \mathrm{~g}$ of urea, $20 \mathrm{~mL}$ of $\mathrm{M} \mathrm{H}_{3} \mathrm{PO}_{4}$ and $80 \mathrm{~mL}$ of $90 \%$ ethanol. The plates were dried in an oven at $80^{\circ} \mathrm{C}$ overnight.

The quantitative analysis was done by HPLC with a refractive index detector using the shodex column $(4.6 \mathrm{~mm} \times 25 \mathrm{~cm}, 5 \mu \mathrm{m})$. The analysis was done at room temperature with acetonitrile: water (75:25) as mobile phase at a flow rate of $1.0 \mathrm{~mL} \mathrm{~min}{ }^{-1}$. The final FOS yield was expressed as the percentage conversion yield based on the initial sucrose concentration.

\section{RESULTS AND DISCUSSION}

The main objective of this research was to produce FOS through immobilization technique and the fructooligosaccharides production was made at controlled $\mathrm{pH}$ 5.5. Using both extracellular and intracellular enzyme reacting with $55 \%$ concentration of sucrose.

Production of FOS: Using immobilization technique of cells their often occurs causes some changes in kinetic patterns of the resulting product. When extracellular enzyme was used the FOS concentration was observed after $42 \mathrm{~h}$ which corresponded to $46 \%$ but when intracellular enzyme was used the FOS concentration was little higher $54 \% \mathrm{w} / \mathrm{w}$. The samples were taken at regular intervals after $2 \mathrm{~h}$ of reaction FOS formation was $15 \%$ and goes on increasing and reaches upto $46 \%$ by using extracellular enzyme (Fig. 4) but in intracellular enzyme it was $20 \%$ after $2 \mathrm{~h}$ of reaction and reaches $54 \%$ during end of reaction time $42 \mathrm{~h}$ (Fig. 5). Concentration of sucrose was much in the beginning but it soon becomes less as the fructosyl enzymes transfers fructose molecules from one sucrose molecules which acts as donor and transfers it to next sucrose molecules which acts as recipient forms large oligomers like kestose $\left(\mathrm{GF}_{2}\right)$ and nystose $\left(\mathrm{GF}_{3}\right)$. There was no formation of fructofuranosyl nystose $\left(\mathrm{GF}_{4}\right)$ upto $22 \mathrm{~h}$ but after $30 \mathrm{~h}$ of reaction its formation starts and goes on increasing and reaches upto $4 \%$ in $48 \mathrm{~h}$. Fructose in the reaction was less in beginning but goes on increasing because fructosyltransferase enzyme transferase fructose from one sucrose molecules to another. Also in case of glucose it was less in the beginning but as the reaction proceeds it was liberated free and it inhabits for fructooligosaccharides production.

These conditions are identical to those reported by Jung et al. (1993) and Sangeetha et al. (2004) with FTF isolated from AP. However, the yield of conversion, the sugar composition and the kinetic for the enzyme reaction

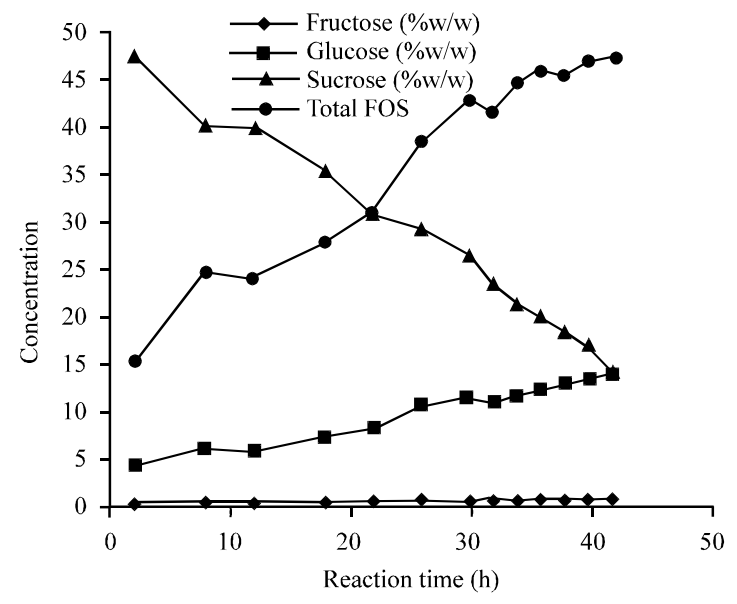

Fig. 4: Concentration of FOS in $42 \mathrm{~h}$ using extracellular enzyme

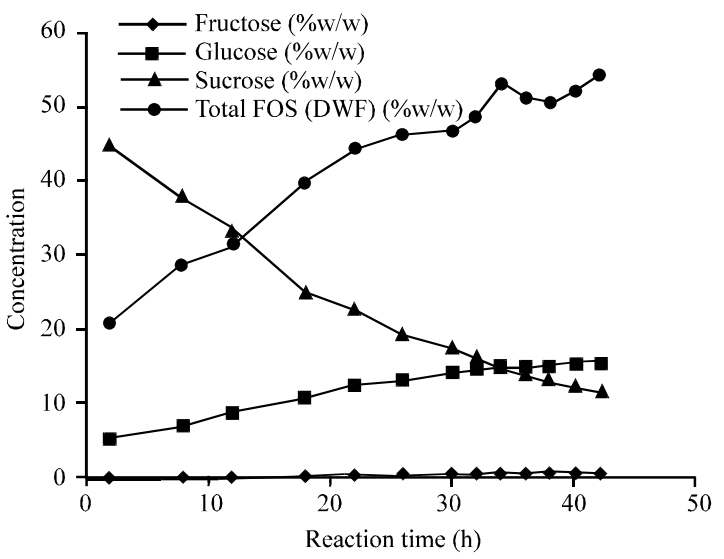

Fig. 5: Concentration of FOS during $42 \mathrm{~h}$ using intracellular enzyme

were different. Their yield of conversion was markedly higher than the results. Yun et al. (1994) demonstrated that the conversion yield obtained using FTF alone is limited to only $55-60 \%(\mathrm{w} / \mathrm{w})$ because the glucose liberated during the enzymatic reaction acts as a competitive inhibitor. To enhance FOS conversion, they suggested using a mixed system constituted of FTF combined with enzymes able to eliminate glucose in the reaction mixture. They obtained very good results using a system containing FTF and glucose oxidase (Yun et al., 1994). Under optimal conditions, sucrose was completely consumed in $25 \mathrm{~h}$, glucose was converted into gluconic acid and conversion yields up to $90 \%$ were obtained. This system is nevertheless not ideal because of the glucose oxidase being inactive at high temperature and the reaction has to be carried out at $55^{\circ} \mathrm{C}$ with limited sucrose concentration of $55 \% \mathrm{w} / \mathrm{v}$. Sangeetha et al. (2004) used 
both culture fluid and intracellular enzyme of Aureobasidium Pollulans CFR 77 and their result was 55\% of culture fluid and $56 \%$ of intracellular enzyme in $24 \mathrm{~h}$ of reaction mixture. But their sucrose concentration was $80 \%$.

\section{CONCLUSION}

Using fructosyltransferase enzyme from Aureobasidium pullulans both the extracellular and intracellular cell mass were immobilized in sodium alginate to form small gel beads. About $5.2 \mathrm{~g}$ of beads was reacted with $55 \%$ concentration of sucrose and resultant product was $54 \%$ of FOS which is much $>46 \%$ from extracellular enzyme.

\section{REFERENCES}

Gibson, G.R. and M.B. Roberfroid, 1995. Dietary modulation of the human colonic microbiota: Introducing the concept of prebiotics. J. Nutr., 125: 1401-1412.

Hara, K., K. Fujita, N. Kuwahara, T. Tanimoto, H. Hashimoto, K. Koizumi and S. Kitahata, 1994. Galactosylation of cyclodextrins and branched cyclodextrins by á-galactosidases. Biosci. Biotech. Biochem., 58: 652-659.

Hidaka, H., M. Hirayama and N. Sumi, 1988. A fructooligosaccharide producing enzyme from Aspergillus niger ATCC 20611. Agric. Biol. Chem., 52: 1181-1187.

Hidaka, H.T., T. Eida, T. Takizawa, T. Tokunaga and Y. Tashiro, 1986. Effect of fructooligosaccharides on intestinal flora and human health. Bifidobacteria Microflora, 5: 37-50.

Jung, K.H., J.H. Kim, Y. Yeon and J. Lee, 1993. Production of fructooligosaccharide syrup with two enzyme system of fructosyltransferase and glucose oxidase. Biotechnol. Lett., 15: 65-70.

Kohmoto, T., F. Fukui, H. Takaku and T. Mitsuoka, 1991. Dose-response test of isomaltooligosaccharides for increasing fecal bifidobacteria. Agric. Biol. Chem., 55: 2157-2159.
Moore, N., C. Chao, L.P. Yang, H. Storm, M. Oliva-Hemker and J.M. Saavedra, 2003. Effects of fructooligosaccharide-supplemented infant cereal: A double-blind, randomized trial. Br. J. Nutr., 90: 581-587.

Oku, T., T. Tokunaga and N. Hosoya, 1984. Nondigestibility of a new sweetener, Neosugar, in the rat. J. Nutr., 114: 1574-1581.

Sangeetha, P.T., M.N. Ramesh and S.G. Prapulla, 2005. Fructooligosaccharide production using fructosyl transferase obtained from recycling culture of Aspergillus oryzae CFR 202. Process Biochem., 40: 1085-1088.

Sangeetha, P.T., Ramesh, M.N. and S.G. Prapulla, 2004. Production of fructooligosaccharides by fructosyltransferase from Aspergillus oryzae CFR 202 and Aureobasidium pullulans CFR 77. Process Biochem. J., 39: 753-758.

Tokunaga, T., T. Oka and N. Hosoya, 1989. Utilization and excreation of a new sweetener, fructooligosaccharides (neosugar), in rats. J. Nutr., 119: 553-559.

Wada, K., J. Watanabe, J. Mizutani, M. Tomoda, H. Suzuki and Y. Saitoh, 1992. Effect of soyabean oligosaccharides in a beverage on human fecal flora and metabolites. Nippon Nogeikagaku kaishi, 66: 127-135.

Yun, J.W. and S.K. Song, 1993. Production of highcontent fructo-oligosaccharides by the mixed-enzyme system of fructosyltransferase and glucose oxidase. Biotechnol. Lett., 15: 573-576.

Yun, J.W., 1996. Fructooligosaccharides-occurrence: Preparation and application. Enzyme Microb. Technol., 19: 107-117.

Yun, J.W., M.G. Lee and S.K. Song, 1994. Batch production of high content fructo-oligosaccharides from sucrose by the mixed-enzyme system of $\beta$ Fructofuranosidase and glucose oxidase. J. Fermentation. Bio. Eng., 77: 159-163. 